\title{
EFFECT OF DIETARY BLENDED ORGANIC ACID ON GROWTH, DIGESTIBILITY AND IMMUNITY OF AFRICAN CATFISH (Clarias garipenus)
}

\author{
Marwa M.A. Saleh ${ }^{1^{\star}}$, Amer $^{2}$ M.A. and Osman ${ }^{2}$ M.F. \\ 1- General Authority of Agric. Reform, Ministry of Agric., EL-Dokki, Giza, Egypt \\ 2- Animal Production Dept., Fac. of Agric., Ain Shams Univ., P.O. Box 68, Hadayek Shobra \\ 11241, Cairo, Egypt \\ *Corresponding author: marwamohamedsaleh18@Gmail.com \\ Received 11 June, 2018 \\ Accepted 30 July, 2018
}

\begin{abstract}
The present experiment was conducted to evaluate the effect of acidifiers on growth performance and immunity of the African catfish $C$. gariepinus. This experiment was carried out in the wet lab of Fish Production Branch, Department of Animal Production, Faculty of Agriculture, Ain Shams University. A total of 120 fish were selected as healthy catfish which had a uniform size and average weight of $94.93 \pm 0.89 \mathrm{~g}$. A thirty of catfish were used in each treatment divided into three replicates as (10 fish/ quadrate tank). Four experimental diets were formulated at $35 \%$ crude protein with different levels of organic acid blend $(O A B)$; diet was supplemented with $0,2,4$ and $6 \mathrm{ml}$ of organic acid per kilogram diet. Growth parameters, apparent digestibility of crude protein and ether extract were measured. The chemical proximate analysis for whole-body of fish was conducted at the end of the experimental period. Hematological parameters of fish and liver function enzymes were also measured. The fish group fed on $0.6 \%$ organic acids blend showed the highest significance $(\mathrm{P}<$ $0.05)$ increase in total weight gain $(438 \pm 14.24 \mathrm{~g})$, specific growth rate, best feed conversion ratio, feed efficiency ratio and highest protein efficiency than the rest of experimental groups. The highest apparent digestibility for crude protein were achieved in the third fish group which fed diet supplemented with acidifiers at $4 \mathrm{ml} / \mathrm{kg}$ diet and have significant difference $(P<0.05)$ with other groups. Data obtained in hepatosomatic index \% showed no significant difference among different treatment refers to the health status of liver. However, ALAT
\end{abstract}

and ASAT recorded high values in the higher group of OAB-treated fish indicating that liver could be affected. Hematological parameters were in normal range except for $\mathrm{PCV}, \mathrm{Hb}, \mathrm{RBCs}$, and WBCs count which were decreased in the high dose of treated fish. Finally, it could be concluded that using of acidifiers as feed additives at lower doses can enhance growth, productivity and immunity of the African catfish (C. gariepinus).

Keywords: Catfish, Organic acid, Growth, Survival rate, Nutrients digestibility, Immunity

\section{INTRODUCTION}

Feed additives play an important role in the future of aquaculture diets. However, the utilization of organic acids to improve growth performance is widely used in farm livestock, the research conducted on organic acids in aquaculture is very limited. Most of the studies done on rainbow trout (Hernández et al 2012), tilapia (Li et al 2009), red sea bream (Hossain et al 2007) and white shrimp (Su et al 2014). A broad range of organic acids, salts or admixtures are used to improve growth, feed utilization and disease resistance in fish. Routine use of antibiotics as growth promoters is a matter of debate in the animal farming industry. In the field of aquaculture, the inclusion of antibiotics in fish diets (Ahmad and Matty, 1989) can promote growth and feed conversion. But the use of low levels of these antibiotics in fish feeds possesses the possibility to transfer bacterial immunity to pathogenic species in animals and humans (Liem, 2004). Recently research directed into the 
utilization of acidifiers as growth enhancer in fish feeds (Silva et al 2013; Chuchird et al 2015; Ng and Koh, 2017). Acidifiers are functioning as conserving agent by reducing the $\mathrm{pH}$ of the feed, thereby inhibiting microbial growth, thus lower the possibility of uptake pathogenic organisms and their toxic metabolites by the farmed animals. Due to the specific spectrum of each of the organic acids, organic acids blend is widely used in animal feed. The organic acids blend has a broader spectrum effect on the pathogenic bacteria than each of the organic acid alone. Also, the use of organic acids blend led to reduction of the dose used in animal feeds, which consequence reduce the costs (Dibner and Buttin, 2002).

The aim of the present experiment was to investigate the effect of acidifier on growth performance, feed utilization, digestibility and the immunity of the African catfish (Clarias gariepinus).

\section{MATERIALS AND METHODS}

\section{Location of the experiment}

The study was carried out in the wet lab of Fish Production Branch, Department of Animal Production, Faculty of Agriculture, Ain Shams University, in a recirculating system. The study was started from $1 / 12 / 2015$ to $30 / 5 / 2016$ included 21 days as adaptation period.

\section{Description of the rearing system}

Fish were kept in quadrate fiberglass tanks (60 $\times 60 \times 40 \mathrm{~cm}$ ) supplied with dechlorinated water in a recirculating system. Each quadrate fiberglass tank had a central stand pipe to remove any of the accumulated excreta; tanks were weekly cleaned to remove any of the residual's adhesive in the tank. Water in each tank was continuously aerated by air stones connected to air blower. Three tanks were used as replicates for each treatment.

\section{Water quality}

Water temperature and dissolved oxygen were measured by Mettler Toledo, model 128, s/no 1242 , the average water temperature was $24.30 \pm$ $1.1^{\circ} \mathrm{C}$ and dissolved oxygen was above $5.4 \pm 0.5$ $\mathrm{mg} / \mathrm{l}$. Water $\mathrm{pH}$ and ammonia were measured every two days by $\mathrm{pH}$ meter (Orion model $720 \mathrm{~A}$, s/no 13062) and ammonia by Hanna ammonia meter, the average level of ammonia was $0.012 \pm 0.02$ $\mathrm{mg} / \mathrm{l}$ and $\mathrm{pH}$ was $7.7 \pm 0.7$ throughout the experi- mental period. All water quality parameters were within the accepted levels for African catfish (Boyd, 1984).

\section{Fish}

Juveniles Clarias gariepinus were obtained from the private fish farm, EL-Manzala, Port Said, Egypt. Fish were acclimated in indoor tanks for 21 days, after that a total of 120 fish were selected as healthy catfish which had a uniform size with an average weight of $94.93 \pm 0.89 \mathrm{~g}$. Fish in each tank were weighed every two weeks to avoid handling stress.

\section{Diet formulation and feeding regime}

Four experimental diets were formulated with different levels of organic acids (Table 1). Fish feed row ingredients were bought from the local market. Feed pellets were prepared by using electrical meat mincer, then sun dried, packed in bags and frozen until use. Diet was supplemented with $0,2,4$ and $6 \mathrm{ml}$ of organic acid blend per kilogram diet. Fish were daily fed three times at 7:00 am, $12: 00 \mathrm{pm}$ and $4: 00 \mathrm{pm}$ at a rate of $3 \%$ of its body mass. The proximate chemical analysis of the diet composition (\%) on dry matter basis is summarized in (Table 2).

\section{Acidifiers}

Dietary acidifier used in the present experiment was a blend of organic acids which was formulated according to $\mathrm{OAB}$ blend. The OAB was prepared by adding $55.4 \mathrm{ml}$ formic acid (85\%) and $27 \mathrm{ml}$ phosphoric acid (85\%) and $10.1 \mathrm{ml}$ of acetic acid was added to the previous solution, then $5.8 \mathrm{~g}$ of citric acid powder plus $1.1 \mathrm{~g}$ of copper sulfate were dissolved in $7.5 \mathrm{ml}$ distilled water to obtain $100 \mathrm{ml}$ of a final organic acid blend (OAB) solution. Each $100 \mathrm{ml}$ of this solution were used in three treatments as 2, 4, and $6 \mathrm{ml}$ per kilogram diet.

\section{Design of the experiment}

One hundred and thirty catfish were used in the present experiment, where 10 fish were sacrificed as a zero group for body composition analysis. The rest (120 fish) were divided randomly into 4 fish groups, where thirty fish were used in each treatment divided into three replicates as (10 fish/ tank). Groups 1, 2, 3, 4 were fed one of the formulated diets, where the ratios of acidifiers included in the diets were $0 \%, 0.2 \%, 0.4 \%$ and $0.6 \%$, respectively. 
Table 1. Diet formulation

\begin{tabular}{|l|c|c|c|c|}
\hline Ingredients & $\begin{array}{c}\text { T1 } \\
\text { Without } \\
\text { OAB }\end{array}$ & $\begin{array}{c}\text { T2 } \\
\text { 2ml OAB/ } \\
\text { diet }\end{array}$ & $\begin{array}{c}\text { T3 } \\
\text { 4ml OAB/ } \\
\text { diet }\end{array}$ & $\begin{array}{c}\text { T4 } \\
\text { 6ml OAB/ } \\
\text { diet }\end{array}$ \\
\hline Yellow corn & 31.7 & 31.5 & 31.3 & 31.1 \\
Residues of poultry slaughter & 25 & 25 & 25 & 25 \\
Fish oil & 1 & 1 & 1 & 1 \\
Soy oil & 1 & 1 & 1 & 1 \\
Rice bran & 7 & 7 & 7 & 7 \\
Soy 48\% & 20 & 20 & 20 & 20 \\
Fishmeal 65\% & 10.3 & 10.3 & 10.3 & 2 \\
Salt & 2 & 2 & 2 & 2 \\
Vit. Premix & 2 & 2 & 2 & 0.3 \\
Organic acid blend (OAB) & 0 & 0.2 & 0.4 & 2 \\
\hline
\end{tabular}

Table 2. The proximate chemical analysis of diet composition (\% on DM basis)

\begin{tabular}{|l|c|}
\hline Moisture \% & 8.7 \\
Crude protein \% & 35 \\
Crude fiber \% & 5.31 \\
Ether extract \% & 10.35 \\
Ash \% & 7.1 \\
Total carbohydrates & 42.24 \\
Gross energy (Kcal/100g) & $490.5 \mathrm{Kcal} / 100 \mathrm{~g}$ \\
\hline
\end{tabular}

Parameters of growth performance

\section{- Total weight gain}

$\mathrm{TG}(\mathrm{g})=\mathrm{W}_{1}-\mathrm{W}_{0}$ as $W_{1}=$ the final weight $(g), W_{0}=$ the initial weight $(g)$.

\section{- Specific growth rate}

SGR \% = 100 (Ln final weight - Ln initial weight)/ period (days).

\section{- Average daily gain}

$A D G=\left(W_{1}-W_{0}\right) /$ days of feeding in the experimental period.

\section{- Relative growth rate}

RGR $=$ wt. gain by fish $(g) /$ Initial body wt. (g) $\times 100$.

\section{Feed utilization parameters}

\section{- Feed conversion ratio}

FCR = Feed intake (g)/ Weight gain (g).

\section{- Feed efficiency ratio}

$$
\text { FER = Weight gain (g)/ Feed intake (g). }
$$

\section{Protein utilization parameters}

\section{- Protein efficiency ratio}

PER $=$ Total weight gain/ Protein intake

\section{- Protein productive value (\%)}

PPV $\%=$ Protein gain (g)/ Protein intake $(\mathrm{g})$ $\times 100$.

\section{Survival rate}

SR $\%=($ No. fish at the final $/$ No. fish at the start) $\times 100$.

\section{Digestibility trial}

By the end of the growing period, a group of 4 fish in each treatment were fed for 21 days the same feeding regime and feces were collected by siphon and by the central standpipe, then the total fecal was obtained by the basic pipe outlet and placed in a fine mesh net, fecal samples were removed and collected immediately on filter paper. Fecal materials of each treatment were blended together and dried at $60^{\circ} \mathrm{C}$ in the oven and kept at $-20 \stackrel{\circ}{\circ}$. Apparent digestibility coefficient of crude protein and ether extract were measured according to the direct methods (Bureau et al 1999; Zhou et al 2004). 
[100x (protein in diet - protein in feces)/ protein in diet].

[100× (E.E. in diet - E.E. in feces) / E.E. in diet].

\section{Proximate analysis of whole-body composition}

The chemical proximate analysis for whole body of fish was conducted according to Association of Official Analytical Chemists (AOAC, 1995). At the end of experimental period, from each tank a random 3 fish were selected, pooled, ground and frozen in poly ethylene bags for determination of body crude protein, lipid, ash and moisture.

\section{Blood sampling and biochemical analysis}

At the end of the experimental period, blood samples were collected from the caudal vein of each fish using syringes transferred to heparinized Eppendorf tubes (10 units/ $\mathrm{ml}$ ). Alanine aminotransferase (ALAT) and aspartate aminotransferase (ASAT) enzymes were measured according to (Reitman and Frankel, 1957) to examine the status of liver function.

\section{Hematological parameters}

Hematocrit (packed cell volume, PCV \%) and hemoglobin $(\mathrm{Hb})$ values $(\mathrm{g} / \mathrm{dl})$ were determined according to (Dacie and Lewis, 1975). Red blood cells (RBCs) and white blood cell (WBCs) were counted by a Neubauer hemocytometer. Mean corpuscular volume (MCV), mean corpuscular hemoglobin $(\mathrm{MCH})$ and mean corpuscular hemoglobin concentration ( $\mathrm{MCHC}$ ) were calculated by using the formula according to (Dacie and Lewis, 1975).

$$
\begin{aligned}
& \mathrm{MCV}=(\mathrm{PCV} \% \times 10 / \mathrm{RBCs}) \text { as } \mu \mathrm{m}^{3} . \\
& \mathrm{MCH}=(\mathrm{Hb} \mathrm{g} / \mathrm{dl} / \mathrm{RBCs}) \times 10 \mathrm{as}(\mathrm{pg}) . \\
& \mathrm{MCHC}=(\mathrm{Hb} \mathrm{g} / \mathrm{dl} / \mathrm{PCV} \%) \times 100 \mathrm{as} \% .
\end{aligned}
$$

Hepato-somatic index (HSI) were calculated by:

$\mathrm{HSI}=$ Liver weight $(\mathrm{g}) /$ Fish body weight $(\mathrm{g}) \times 100$

\section{Statistical Analysis}

The obtained data were analyzed statistically by submitting one-way analysis of variance (ANOVA) using the general linear model procedure of the SPSS statistical software package version 18.0 (SPSS Inc., 2009). The test of significance between means was carried out by using Tukey's post-hoc test considering the significance level of $(\mathrm{P}<0.05)$

\section{RESULTS AND DISCUSSION}

\section{Growth Performance}

The effect of acidifier's supplementation on growth performance and feed utilization of Clarias gariepinus are summarized in Table 3. Fish groups fed on $0.6 \%$ blended organic acids (group 4) showed the highest significance $(P<0.05)$ increase in total weight gain $(438 \pm 14.24 \mathrm{~g} / \mathrm{fish})$, average daily gain (ADG) $(2.6 \mathrm{~g} /$ day) and specific growth rate (SGR) $(1.04 \% /$ day). The total weight gain (TWG) improved significantly $(P<0.05)$ by increasing the levels of dietary acidifiers $0.2 \%$ and $0.4 \%$ comparing with the control diet (no acidifier). Total weight gain (TWG) and specific growth rate (SGR) of Clarias gariepinus fed dietary acidifiers at $0.4 \%$ was not differ significantly $(P>0.05)$ from that fed $0.2 \%$, however, SGR of the group 2 was not differ significantly with the control group (Table 3). Average daily gain (ADG) was significantly higher at level $0.6 \%$ and $0.4 \%$ of dietary organic acids recording the highest value of $2.61 \pm 0.08$, $2.03 \pm 0.04 \mathrm{~g}$, respectively, compared with the basal diet and $0.2 \%$ of dietary organic acids. The highest significant value of relative growth rate (RGR) $474.56 \pm 13.01 \%$ was recorded in the fourth treatment at level $0.6 \%$ of organic acid blend, whereas the lowest value $(298.76 \pm 17.44$ $\%)$ was recorded in the control diet. In the present study, African catfish fed blended organic acidifier in diets tended to increase final body weights and specific growth rates (SGR) compared to fish fed on the control diet. The same results were found by (Romano et al 2015; Sherif and Doaa, 2013) who tested $\mathrm{OAB}$ blend at different levels ranged from $1 \%$ to $4 \%$; or $0.1 \%$ to $0.3 \%$ OAB tested by $\mathrm{Ng}$ et al (2009). On the contrary, Anuta et al (2011) found no significant differences $(P>0.05)$ in growth performance parameters of white leg juvenile shrimp when fed diets containing calcium sulfate acidifier (vitoxal). Also, Romano et al (2016) found no significant response in growth weight parameters, when they fed tilapia fish diets included different levels ( 1 to $4 \%$ ) of sodium citrate acidifier. These differences in the previous results which using acidifiers in diets may be contributed to some variations among fish species, size, strain, age, nutrient content of experimental diet and level of acidifiers and their compositions, in addition to the rearing culture system, water quality and feeding management. 
African catfish (Clarias garipenus)

Table 3. Effect of dietary acidifiers on growth performance and feed utilization of Clarias gariepinus

\begin{tabular}{|c|c|c|c|c|c|c|c|c|}
\hline Parameter & IW & FW & ADG & TWG & SGR & RGR & FCR & FER \\
\hline \multirow{2}{*}{ T1 } & 96.83 & 385.96 & 1.72 & 289.12 & 0.82 & 298.76 & 1.82 & 0.55 \\
& \pm 0.79 & $\pm 15.00^{\mathrm{b}}$ & $\pm 0.09^{\mathrm{b}}$ & $\pm 15.42^{\mathrm{c}}$ & $\pm 0.026^{\mathrm{c}}$ & $\pm 17.44^{\mathrm{c}}$ & $\pm 0.09^{\mathrm{a}}$ & $\pm 0.03^{\mathrm{b}}$ \\
T2 & 95.50 & 415.37 & 1.90 & 319.87 & 0.87 & 334.74 & 1.68 & 0.60 \\
& \pm 2.42 & $\pm 16.20^{\mathrm{b}}$ & $\pm 0.08^{\mathrm{b}}$ & $\pm 14.09^{\mathrm{b}}$ & $\pm 0.01^{\mathrm{bc}}$ & $\pm 8.80^{\mathrm{bc}}$ & $\pm 0.06^{\mathrm{b}}$ & $\pm 0.01^{\mathrm{b}}$ \\
T3 & 95.00 & 436.25 & 2.03 & 341.25 & 0.91 & 359.30 & 1.64 & 0.61 \\
& \pm 1.64 & $\pm 7.53^{\mathrm{b}}$ & $\pm 0.04^{\mathrm{a}}$ & $\pm 6.59^{\mathrm{b}}$ & $\pm 0.01^{\mathrm{b}}$ & $\pm 6.67^{\mathrm{b}}$ & $\pm 0.08^{\mathrm{bc}}$ & $\pm 0.02^{\mathrm{b}}$ \\
T4 & 92.40 & 530.88 & 2.61 & 438.48 & 1.04 & 474.56 & 1.40 & 0.72 \\
& \pm 1.81 & $\pm 15.33^{\mathrm{a}}$ & $\pm 0.08^{\mathrm{a}}$ & $\pm 14.24^{\mathrm{a}}$ & $\pm 0.01^{\mathrm{a}}$ & $\pm 13.01^{\mathrm{a}}$ & $\pm 0.08^{\mathrm{c}}$ & $\pm 0.03^{\mathrm{a}}$ \\
\hline
\end{tabular}

Values (means $\pm \mathrm{SE}$ ) within the same row have different superscript letters indicate significant differences $(\mathrm{P}<0.05)$.

\section{Feed utilization efficiency of $C$. gariepinus}

At the end of the trial, fish showed improvement in feed utilization represented as feed conversion ratio (FCR) and feed efficiency ratio (FER). The acidifiers supplementation in diets had significantly increased $(P<0.01)$ the feed efficiency ratio and achieved the best feed conversion values. The fourth group of fish, which was fed on $0.6 \%$ acidifiers supplemented diet showed the best highly significant $(P<0.01)$ feed conversion ratio and feed efficiency ratio compared to the other groups (Table 3). Our findings agree with those obtained by Sherif and Doaa (2013) who tested cultured Oreochromis niloticus on different doses of $O A B$ and reported a significant improvement in FCR, SGR and survival rates by increasing the level of acidifiers comparing to the control group. Abu Elala and Ragaa (2014) also observed that graded levels of KDF (potassium diformate) 0.2 and $3 \%$ significantly improved FCR. In despite of the previous results, a study showed that there was no significant difference at $(P>0.05)$ among different levels of OAB $(0.1 \%, 0.2 \%$, and $0.3 \%$ organic acid blend) and $0.2 \%$ KDF in red hybrid tilapia ( $\mathbf{N g}$ et al, 2009).

The protein efficiency ratio (PER) was significantly affected by the experimental diets, where the best significant $(P<0.05)$ protein efficiency ratio was found by fish group fed the diet containing the highest level of the acidifier (0.6\%). Whereas no significant effects were recorded between the other experimental treatments (Table 4). The protein productive values (PPV \%) showed that with increasing the acidifier percentage in the experimental diets, protein deposition in fish body was significantly $(P<0.05)$ decreased. Fish group fed diet contained $0.6 \%$ organic acids had the highest significant $(P<0.05)$ protein efficiency ratio (PER) than the rest of experimental groups. It was $30.5 \%$ higher than the control diet. However, the same group (T4) showed the lowest significant ( $P$ $<0.05)$ protein productive value (PPV \%). This is may be due to the higher moisture content and lower protein deposition in fish body found in this group (Table 4). In the present study, the protein efficiency ratio was also increased gradually in T2 and T3 as (8.4 and $11.7 \%$, respectively) more than that of the control diet. Similar findings were recorded by (Hassan et al., 2014; Sherif and Doaa, 2013; Abu-Elala and Ragaa, 2014). The later result of PER is disagreeing with that found by $(\mathbf{N g}$ et al., 2009) who reported that protein efficiency ratio was not significantly different $(P>0.05)$ among different levels of $\mathrm{OAB}(0.1 \%, 0.2 \%$ and $0.3 \%)$.

Table 4. The mean ( \pm SE) of protein utilization efficiency of African catfish (Clarias gariepinus) fed diets containing different levels of blended acidifiers

\begin{tabular}{|l|c|c|c|c|}
\hline Items & T1 & T2 & T3 & T4 \\
\hline PER & $1.75 \pm 0.08^{\mathrm{b}}$ & $1.89 \pm 0.04^{\mathrm{b}}$ & $1.93 \pm 0.05^{\mathrm{b}}$ & $2.28 \pm 0.08^{\mathrm{a}}$ \\
PPV \% & $33.17 \pm 0.05^{\mathrm{bc}}$ & $44.47 \pm 1.90^{\mathrm{a}}$ & $35.76 \pm 0.71^{\mathrm{b}}$ & $30.06 \pm 1.20^{\mathrm{c}}$ \\
\hline
\end{tabular}

Values (means $\pm \mathrm{SE}$ ) within the same row have different superscript letters indicate significant differences $(P<0.05)$. 
Supplementation of the control diet with lower doses of acidifiers significantly improved PPV. The diet supplemented with $0.2 \%$ organic acid had the best protein productive value which increased significantly $(P<0.05)$ as $34.05 \%$ over the control diet. In the present work, the protein productive value decreased gradually in T4 compared to the basal diet. However, the data indicating no signifi- cances difference between T 3, or T4 and the control diet (Fig. 1). This result is similar to that obtained by Hassan et al (2014) for Oreochromis niloticus fed on diet supplemented with $1 \%$ calcium lactate as organic acid salt, they recorded significant increase in protein productive value as (35.04\%) over the other treatments.

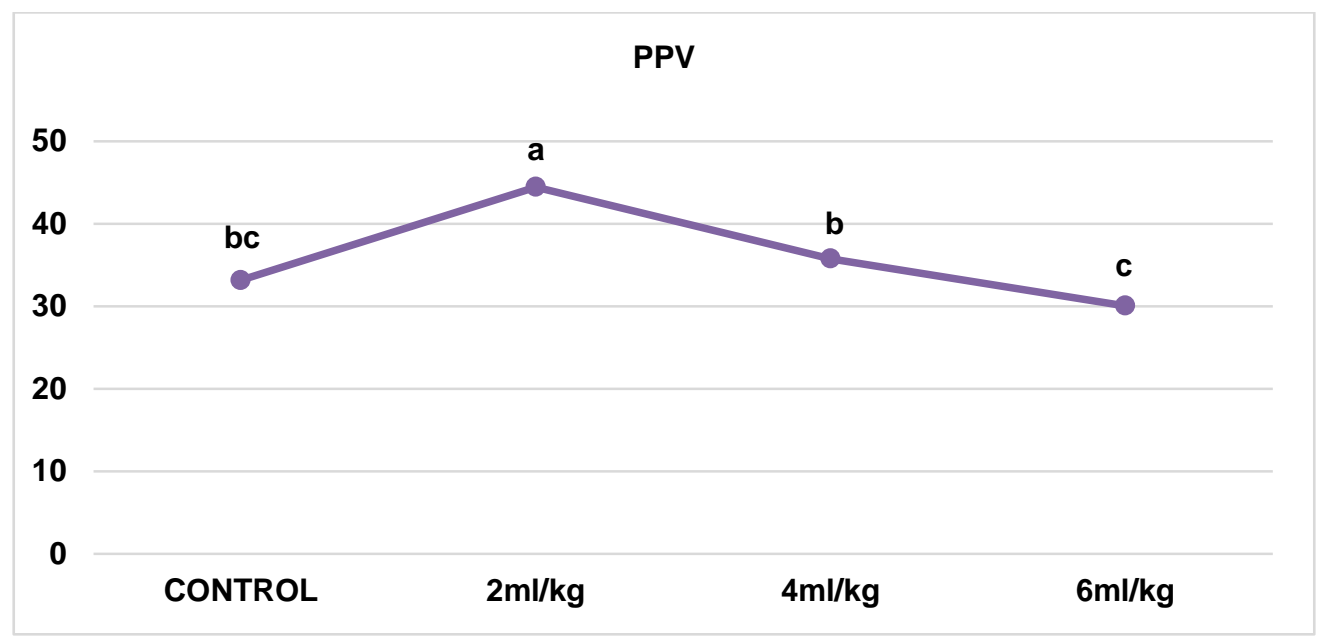

Fig. 1. Protein productive value of Clarias gariepinus at different level of organic acid blend

Several hypotheses have been suggested about the effect of acidifiers on improvements of nutrient's utilization, by lowering $\mathrm{pH}$ in the gut leading to increase pepsin enzyme activation, pancreatic enzyme (trypsin, lipase), intestinal enzyme activities (leucin, amino peptidase and phosphorus) which may increase mineral solubilization as chelating agents binding up various cations along the intestine, leading to increase mineral absorp- tion and decreasing intestinal microbial activity (Castillo et al 2014; De Wet, 2005).

\section{Survival rates}

There were no significance differences $(P<$ 0.05) on the survival rates (Fig. 2) at various levels of organic acidifier.

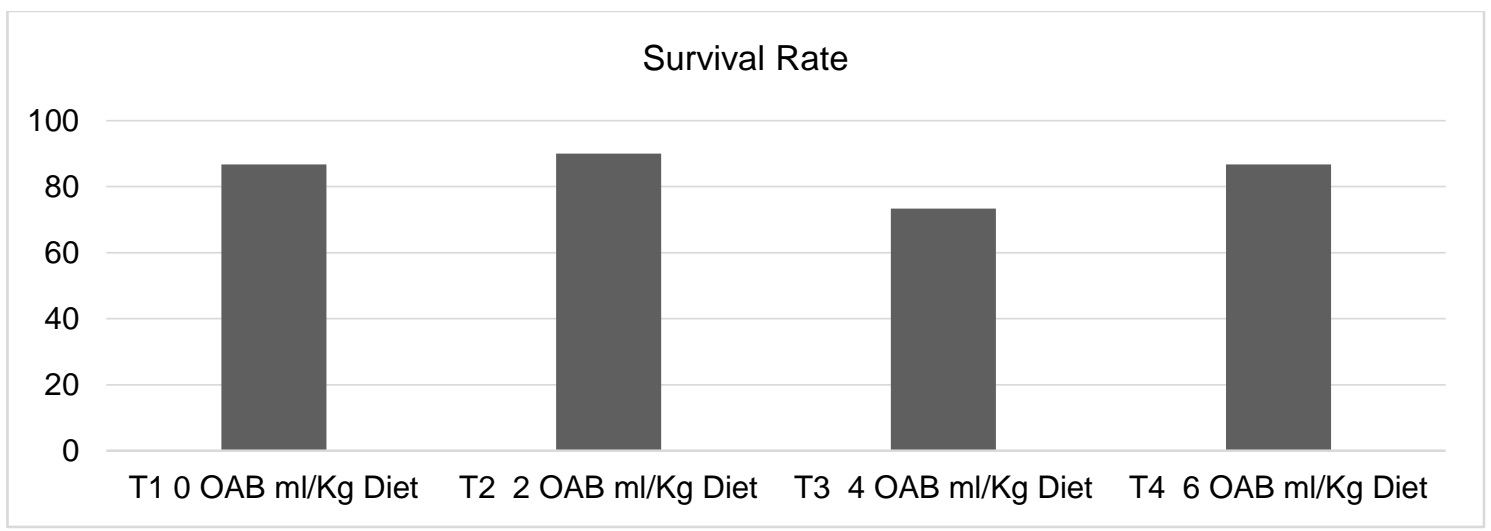

Fig. 2. Survival rates of Clarias gariepinus at different levels of organic acid blend. 


\section{Apparent digestibility coefficient}

Apparent nutrients digestibility among different dietary acidifiers groups are presented in Table 5 . There are no significant differences $(P>0.05)$ in the dry matter digestibility between varied levels of organic acids blend, similar finding to this result with a slight enhancement in the dry matter digestibility was demonstrated by (Silva et al 2013), who fed marine shrimp Litopenaeus vannamei diets supplemented with $2 \%$ salts of organic acid (acetate, propionate and butyrate) and their results showed no significant differences in the apparent dry matter and crude protein digestibility.

In the present study the highest apparent digestibility of crude protein was achieved in the third fish group fed diet supplemented with acidifiers at $4 \mathrm{ml} / \mathrm{kg}$ diet which was significantly different $(P<$ $0.05)$ with other groups. This result could be attributed to some factors such as dietary acidification and solubilization which reduce intestinal $\mathrm{pH}$ and could be also due to binding various cations along the intestine (Khajepour and Hosseini, 2012).

Table 5. Apparent nutrient digestibility coefficient \% of Clarias gariepinus fed acidifiers supplemented diets (data are means \pm SE of three replicates of fecal samples)

\begin{tabular}{|l|c|c|c|c|}
\hline Parameter & T1 & T2 & T3 & T4 \\
\hline Dry matter & $68.32 \pm 3.91$ & $69.81 \pm 3.77$ & $69.68 \pm 1.24$ & $65.51 \pm 3.80$ \\
Crude protein & $55.34 \pm 3.70^{\mathrm{ab}}$ & $40.93 \pm 3.20^{\mathrm{c}}$ & $58.56 \pm 0.45^{\mathrm{a}}$ & $49.70 \pm 1.33^{\mathrm{b}}$ \\
Lipid & $54.80 \pm 1.33^{\mathrm{a}}$ & $5.58 \pm 2.53^{\mathrm{c}}$ & $18.75 \pm 0.91^{\mathrm{b}}$ & $62.45 \pm 5.87^{\mathrm{a}}$ \\
\hline
\end{tabular}

Values within the same row have different superscript letters indicate significant differences $(P<0.05)$.

These results agreed with that found by $(\mathbf{N g}$ et al 2015) who fed tiger shrimp $P$. mondon 1,2 and $4 \%$ organic acid blend diet and found that group fed $2 \%$ organic acid blend had higher significant $(\mathrm{P}<0.05)$ growth performance and higher apparent crude protein digestibility than the other groups. Similar findings were detected by (Hassan et al 2014) on Oreochromis niloticus fed on diet supplemented by calcium lactate and calcium propionate at different levels $0.5 \%, 1 \%$ and $1.5 \%$, the result tends to no significant difference in the dry matter digestibility but showed highly significant difference in the apparent digestibility of crude protein and crude lipids. On the contrary, (Romano et al 2015) tested the microencapsulated organic acids blend on white shrimp Litopenaeus. vannamei at levels of $1 \%, 2 \%$ and $4 \% O A B$ and demonstrated that the highest dry matter digestibility was detected from shrimp fed on $2 \%$ OAB diet.

In previous study ( $\mathbf{N g}$ et al 2009) on red hybrid tilapia fed diets supplemented with different levels of $0.1 \%, 0.2 \%$ and $0.3 \%$ OAB compared to potassium diformate (KDF) at $0.2 \%$ concentration, their results showed that no significant differences in the apparent dry matter, crude protein and crude lipid digestibility among the various treatments. These results could be attributed to the type of acidifiers and species used as experimental aquatic animal.

Table 6. Proximate analysis of whole-body composition of African catfish fed acidifiers supplemented diets

\begin{tabular}{|l|c|c|c|c|}
\hline Parameter & T1 & T2 & T3 & T4 \\
\hline Dry matter & $28.51 \pm 3.52$ & $27.18 \pm 3.39$ & $27.28 \pm 2.11$ & $31.04 \pm 3.42$ \\
Crude protein & $65.87 \pm 1.13^{\mathrm{c}}$ & $74.39 \pm 1.17^{\mathrm{ab}}$ & $78.93 \pm 1.15^{\mathrm{a}}$ & $72.21 \pm 1.94^{\mathrm{b}}$ \\
Crude lipid & $9.25 \pm 0.56$ & $9.46 \pm 2.29$ & $7.32 \pm 0.68$ & $6.81 \pm 0.65$ \\
Ash & $0.71 \pm 0.02^{\mathrm{b}}$ & $0.67 \pm 0.05^{\mathrm{b}}$ & $0.78 \pm 0.01^{\mathrm{ab}}$ & $0.97 \pm 0.06^{\mathrm{a}}$ \\
\hline
\end{tabular}

Values (means $\pm \mathrm{SE}$ ) within the same row have different superscript letters indicate significant differences $(P<0.05)$. 


\section{Whole-body composition of C. gariepinus}

The effect of acidifiers supplemented diets on the proximate analysis of whole-body composition of $C$. gariepinus are represented in Table 6 . The highest value of crude protein and ash were recorded at $4 \mathrm{ml} / \mathrm{kg}$ and $6 \mathrm{ml} / \mathrm{kg}$ dietary supplemented with $O A B$, respectively. In this field (Hassan et al 2014) found that the highest values of crude protein and ash were detected at 1 and $1.5 \% \mathrm{Ca}-$ lactate compared with the basal diet or other tested diets for $O$. niloticus. In the present study body moisture was mostly not significantly affected by different levels of acidifiers, this result is in agreement with ( $\mathrm{Ng}$ et al 2009) who tested different levels of dietary KDF and organic acids blend on red hybrid tilapia, they did not find negative effects on fish body composition and any hazard effects or toxicity on all treated fish which appeared to be in healthy status as that of the control. Similar findings were observed by (Romano et al 2015) who found the highest muscle crude protein levels in shrimp fed on $2 \%$ OAB diet, although there are no significant differences from that of the control diet.

\section{Hematological parameters}

Hematological parameters for C. gariepinus fed on acidifiers supplemented diets are represented in Table 7. All fish groups fed on the different doses of organic acids blend showed significant differences $(P<0.05)$ in red blood cells and white blood cells count, the third treatment recorded the highest values of RBCs and WBCs, while in T2 $(0.2 \%)$ and T4 $(0.6 \%)$ WBCs were decreased recorded the lowest counts, respectively. On the contrary (Sherif and Doaa, 2013) demonstrated that the highest record of WBCs was achieved with in- creasing the concentration of acidifier in the diet. Hematological parameters including hemoglobin $(\mathrm{Hb})$, hematocrit $(\mathrm{PCV}), \mathrm{MCV}, \mathrm{MCH}$, and $\mathrm{MCHC}$ are very close in the different levels of acidifiers treated fish and, in the control, except for RBCs, WBCs, $\mathrm{Hb}$ and PCV values which were decreased in (T4) (Table 7). Hastuti and Subandiyono (2018) reported different values of $1.6-1.7 \times 10^{6}$ $\mu \mathrm{l}^{-1}, 175-206.3 \times 10^{3} \mathrm{\mu l}^{-1}, 6.4-7.5 \mathrm{gdl}^{-1}$ and $21.7-$ $26.2 \%$ for RBCs, WBCs, $\mathrm{Hb}$ and PCV, respectively, in the North African farmed catfish, C. gariepinus. However, Erhunmwunse and Ainerua (2013) reported almost similar values of blood parameters in juvenile African catfish, where RBCs (x

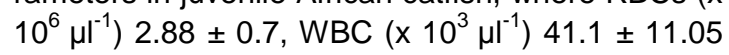
and PCV (\%) $36.0 \pm 9.01$.

Blood profiles can be used to evaluate physiological responses of fish (Hastuti and Subandiyono, 2018). Under stress conditions fish will decrease the number of red blood cells, hematocrit values and hemoglobin levels, while number of white blood cell count tends to be increased (Hastuti, Subandiyono, 2018). The results of this study indicate that WBCs shows the opposite response, i.e. the WBCs value was decreased in the T4 (Table 7), and the values of RBCs, $\mathrm{Hb}$, and hematocrit were also decreased. Similar trend of hematological parameters were observed in the African catfish reared under stress of high stocking density (Hastuti and Subandiyono, 2018). Decreasing of the WBCs value in $6 \mathrm{ml}^{-1}$ OAB-treated fish along with number of RBCs, hematocrit and hemoglobin indicates that the immune system of the fish is weak, so its body will be vulnerable to the threat of infections. Moreover, hematology test could be a good indicator for the quality and safety of the diet.

Table 7. Hematological parameters for Clarias gariepinus fed acidifiers supplemented diets

\begin{tabular}{|l|c|c|c|c|}
\hline Parameter & T1 & T2 & T3 & T4 \\
\hline Hematocrit (PCV \%) & $30.47 \pm 3.79$ & $31.33 \pm 2.85$ & $32.33 \pm 2.85$ & $24.00 \pm 2.00$ \\
Hemoglobin $(\mathrm{g} / \mathrm{dl})$ & $10.27 \pm 1.19$ & $10.57 \pm .93$ & $10.37 \pm 1.19$ & $8.23 \pm 0.38$ \\
RBC $\left(\times 10^{6} \mu \mathrm{l}\right)$ & $3.80 \pm 0.50^{\mathrm{ab}}$ & $3.50 \pm 0.21^{\mathrm{b}}$ & $4.27 \pm 0.09^{\mathrm{a}}$ & $2.83 \pm 0.12^{\mathrm{c}}$ \\
WBC $\left(\times 10^{3} \mu \mathrm{l}\right)$ & $20.31 \pm 2.67^{\mathrm{b}}$ & $18.69 \pm 1.09^{\mathrm{c}}$ & $22.80 \pm 0.47^{\mathrm{a}}$ & $15.14 \pm 0.64^{\mathrm{d}}$ \\
MCV $\left(\mu \mathrm{m}^{3}\right)$ & $84.23 \pm 3.99$ & $88.17 \pm 3.41$ & $79.33 \pm 2.96$ & $82.33 \pm 2.90$ \\
MCH $(\mathrm{pg})$ & $27.33 \pm 3.17$ & $29.33 \pm 1.33$ & $25.00 \pm 2.64$ & $27.33 \pm 1.66$ \\
$\mathrm{MCHC}(\%)$ & $33.00 \pm 1.00$ & $33.00 \pm 0.57$ & $31.67 \pm 1.45$ & $31.67 \pm 0.72$ \\
\hline
\end{tabular}

Values (means $\pm \mathrm{SE}$ ) within the same row sharing the same superscripts are not significantly different $(\mathrm{P}>0.05)$. 
African catfish (Clarias garipenus)

\section{Biochemical analysis of liver enzymes}

Table 8. HSI and liver enzymes of $C$. gariepinus fed acidifiers supplemented diets

\begin{tabular}{|l|c|c|c|c|}
\hline Parameter & T1 & T2 & T3 & T4 \\
\hline \multirow{2}{*}{ HSI \% } & 1.4 & 1.4 & 2.03 & 1.2 \\
& \pm 0.01 & \pm 0.13 & \pm 0.4 & \pm 0.15 \\
ALAT $\left(\mathbf{U I}^{-1}\right)$ & 48.3 & 61.0 & 75.6 & 113.0 \\
& $\pm 2.9^{\mathbf{b}}$ & $\pm 14.4^{\mathbf{b}}$ & $\pm 6.5^{\mathrm{ab}}$ & $\pm 15.3^{\mathbf{a}}$ \\
& 311.6 & 303.3 & 335.0 & 374.3 \\
ASAT $\left(\mathbf{U I}^{-1}\right)$ & \pm 18.8 & \pm 20.3 & \pm 29.3 & \pm 21.3 \\
\hline
\end{tabular}

Values (means $\pm \mathrm{SE}$ ) within same row sharing the same superscripts are not significantly different $(P>0.05)$.

The results showed a slight increase in hepatosomatic index (HIS \%) in T3 compared with other treated and non-treated fish groups. Liver appeared normal with no hemorrhages or tissues damage indicating no hazard effects of dietary supplementation of acidifiers. Similar result was obtained by $(\mathbf{N g}$ et al 2015; Sherif and Doaa 2013; Ng et al 2009; Abu Elala and Ragaa 2014). However, fish fed dietary supplemented with $6 \%$ acidifiers had higher values of ALAT and ASTA enzymes compared with the other treatments (Table 8). ALAT and ASAT enzymes are important indicators for the status of liver function, when large amounts of ALAT and ASAT released into blood will refer to liver cell damage (Suharjo and Cahyono, 2009; Jafarpour and Nekuie 2016). The present data showed increase values of ALAT and ASAT with increasing OAB especially in T4, revealing the possibility of liver cell damage. Hastuti and Subandiyono (2018) reported lower concentrations of ASAT $\left(200-232 \mathrm{Ul}^{-1}\right)$ than the values of the present study and almost similar or higher values for ALAT (104 - $\left.108 \mathrm{UI}^{-1}\right)$ in catfish. The authors mentioned that the recorded higher values of ALAT and ASAT in C. gariepinus cultured using biofloc technology is suspected to be due to that fish liver cells work hard to face of stress conditions caused by the high density of 1,000 fish $\mathrm{m}^{-3}$, these values were lower $185.3 \pm 5.0$ $\mathrm{Ul}^{-1}$ and $63.7 \pm 3.2 \mathrm{Ul}^{-1}$ for ASAT and ALAT, respectively in $C$. gariepinus cultured at lower density of 200 fish $\mathrm{m}^{-3}$ (Hastuti and Subandiyono, 2013). Jafarpour and Nekuie (2016) reported lower values of $\left(44.5 \pm 6.1 \mathrm{UI}^{-1}\right)$ for ALAT and $(38.5 \pm 8.9$ $\mathrm{UI}^{-1}$ ) for ASAT in Oncorhynchus mykiss which are very close with those of the control group. On other hand (Romano et al 2016) demonstrated that the liver from all red hybrid tilapia fish showed some necrosis and hemorrhaging became apparent in the $2 \%$ sodium citrate treated fish, although the authors reported no significant differences were observed with sodium citrate treatments at different levels.

The acidification of the diet markedly reduces the microbial load by reducing gut $\mathrm{pH}$ and due to the diffusion of the organic acids into the bacterial cells which in turn reducing cytoplasmic $\mathrm{pH}$ of bacterial cells, eventually cause cell death (Booth and Stratford, 2003). Finally, there are many factors that may affect the utilization of acidifiers such as species, type of fish culture, physiological status, age, levels of organic acids, in addition to the type of acidifiers used as growth promoters.

\section{CONCLUSION}

The results of this study demonstrated that diet supplemented with acidifiers will improve growth performance, nutrients utilization and immunity for catfish. However, using higher concentrations of $\mathrm{OAB}$ as feed additives for prolonged period may affect liver function and cause liver damage.

\section{REFERENCES}

Abu Elala N.M., Ragaa N.M., 2014. Eubiotic effect of a dietary acidifier (potassium diformate) on the health status of cultured Oreochromis niloticus. J. Advanced Research 6, 621-629.

Ahmad T.S., Matty A.J., 1989. The effect of feeding antibiotics on growth and body composition of carp (Cyprinus carpio). Aquaculture 77, 211-229.

Anuta D.J., Buentello A., Patnaik S., Lawrence A.L., Mustafa A., Hume M.E., Gatlin III, D.M., Kemp M.C., 2011. Effect of dietary supplementation of acidic calcium sulfate (vitoxal) on growth, survival, immune response and gut microbiota of the pacific white shrimp, Litopenaeus vannamei. J. World Aquaculture Society 42, 834-844.

AOAC 1995. Association of Official Analytical Chemists. In: Cunni, P.A. (ed.), Official Methods of Analysis, Vol. 1, $16^{\text {Th }} \mathrm{Ed}$., AOAC International, Arlington, USA, 1298 p.

Booth I.R. and Stratford M. 2003. Acidulants and low pH. In: Russel N.J., Gould G.W. (eds), Food Preservatives. Kluwer Academic Plenum Publishers, New York, USA, pp. 25-47. 
Boyd C.E. 1984. Water management for fish culture. Development in aquaculture and fisheries science Vol. 9, pp. 283-292. Elsevier, USA.

Bureau D.P., Harris A.M. and Cho C.Y. 1999. Apparent digestibility of rendered animal protein ingredients for rainbow trout (Oncorhynchus mykiss). Aquaculture 180, 354-358.

Castillo S., Rosales M., Pohlenz C. and Gatlin D.M. 2014. Effects of organic acids on growth performance and digestive enzyme activities of juvenile red drum Sciaenops ocellatus. Aquaculture, 433, 6-12.

Chuchird N., Rorkwiree P. and Rairat T. 2015. Effect of Formic Acid and Astaxanthin on the Survival and Growth of Pacific White Shrimp (Litopenaeus vannamei) and their Resistance to Vibrio Parahaemolyticus. Springer Plus 4, 440.

Dacie J.V. and Lewis S.M. 1975. Practical hematology. London, Churchill. Livingstone, pp. 616628.

De Wet L. 2005. Organic acids as performance enhancers. Aquafeeds: Formulation and Beyond 2, 12-14.

Dibner J.J. and Buttin P. 2002. Use of organic acids as a model to study the impact of gut microflora on nutrition and metabolism. J. Applied Poultry Research 11, 453-463.

Erhunmwunse N.O. and Ainerua M.O. 2013. Characterization of Some Blood Parameters of African Catfish (Clarias gariepinus). AmericanEurasian J. Toxicological Sciences 5(3), 7276.

Hassaan M.S., Wafa M.A., Soltan M.A., Goda A.S. and Mogheth N.M.A. 2014. Effect of Dietary Organic Salts on Growth, Nutrient Digestibility, Mineral Absorption and Some Biochemical Indices of Nile Tilapia, Oreochromis niloticus L. Fingerlings. J. World Applied Sci. 29(1), 47-55.

Hastuti S. and Subandiyono S. 2018. Haematological parameters of the North African catfish Clarias gariepinus farmed using biofloc technology. AACL Bioflux 11(4), 1415-1424.

Hernández A.J., Satoh S. and Kiron V. 2012. Supplementation of citric acid and amino acid chelated trace elements in low-fish meal diet for rainbow trout affect growth and phosphorus utilization. J. World Aquaculture Society, 43, 688-696.

Hossain M.A., Pandey A. and Satoh S. 2007. Effects of organic acids on growth and phosphorus in red sea bream Pagrus major. Fisheries Sci. 73, 1309-1317.
Jafarpour M. and Nekuie F.A. 2016. The effects of aqueous extract of Melissa officinalis on some blood parameters and liver of Oncorhynchus mykiss. AACL Bioflux 9(3), 748-758.

Khajepour F. and Hosseini S.A. 2012. Citric acid improves growth performance and phosphorus digestibility in Beluga (Huso huso) fed diets where soybean meal partly replaced fish meal. Animal Feed Sci. Technology 171, 68-73.

Li J.S., Li J.L. and Wu T.T. 2009. Effects of nonstarch poly saccharides enzyme, phytase and citric acid on activities of endogenous digestive enzymes of tilapia (Oreochromis niloticus $x$ Oreochromis aureus). Aquaculture Nutrition 15, 415-420.

Liem D.T. 2004. E. coli resistant to most antibiotics in Vietnam. Asian Pork Magazine 8/9, 22-24.

Ng W.K. and Koh C.B. 2017. The utilization and mode of action of organic acids in the feeds of cultured aquatic animals. Reviews in Aquaculture 9, 342-368.

Ng W.K., Koh C.B., Teoh C.Y. and Romano N. 2015. Farm-raised tiger shrimp, Penaeus monodon, fed commercial feeds with added organic acids showed enhanced nutrient utilization, immune response and resistance to Vibrio harveyi challenge. Aquaculture, 449, 69-77.

Ng W.K., Koh C.B., Sudesh K. and Siti-Zahrah A. 2009. Effects of dietary organic acids on growth, nutrient digestibility and gut microflora of red hybrid tilapia, Oreochromis sp., and subsequent survival during a challenge test with Streptococcus agalactiae. Aquaculture Res. 40, 1490-1500.

Reitman S. and Frankel S.A. 1957. Colorimetric determination of glutamic oxaloacetic and glutamic pyruvic transaminases. J. Clinical Pathology 28, 56-63.

Romano N., Watson S., Ebrahimi M., Abdalbast H.I., Chou M.C. and Kamarudin M.S. 2016. Dietary sodium citrate improved oxidative stability in red hybrid tilapia (Oreochromis sp.) but reduced growth, health status, intestinal short chain fatty acids and induced liver damage. Aquaculture, 458, 170-176.

Romano N., Koh C.B. and Ng W.K. 2015. Dietary microencapsulated organic acids blend enhances growth, phosphorus utilization, immune response, hepatopancreatic integrity and resistance against Vibrio harveyi in white shrimp, Litopenaeus vannamei. Aquaculture 435, 228-236. 
Sherif A.H. and Doaa M.G. 2013. Studies on the Effect of Acidifier on Cultured Oreochromis niloticus. J. Arabian Aquaculture Society 8, 229-236.

Silva B.C., Vieira F.N., Mourino J.L.P., Ferreira G.S. and Seiffert W.Q. 2013. Salts of organic acids selection by multiple characteristics for marine shrimp nutrition. Aquaculture 384-387, 104-110.

SPSS 2009. PASW Statistics for Windows, Version 18.0, Chicago, SPSS Inc.
Su X., Li X., Leng X., Tan C., Liu B. and Chai X. 2014. The improvement of growth, digestive enzyme activity and disease resistance of white shrimp by the dietary citric acid. Aquaculture International 22, 1823-1835.

Suharjo J.B. and Cahyono B. 2009. Hepatitis A. $1^{\text {st }}$ edition, Kanisius, Yogyakarta.

Zhou Q.C., Tan B.P., Mai K.S. and Liu Y.J. 2004. Apparent digestibility of selected feed ingredients for juvenile Cobia Rachycentron canadum. Aquaculture 241, 441-451. 


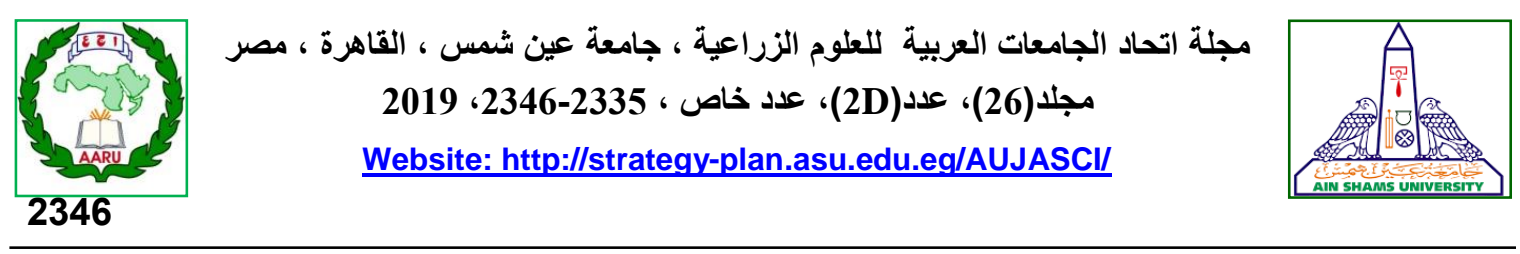

تأثير استخذام مخلوط الأحماض العضوية على النمو والهضم والمناعة لأسماك القراميط

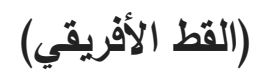

\author{
مروه محمد على صالح" " - محمد عبد الباقى عامر 2- محمد فتحى عثمان2 2

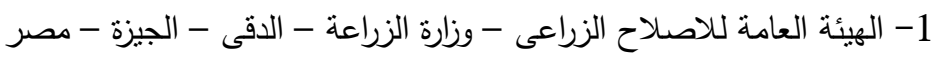

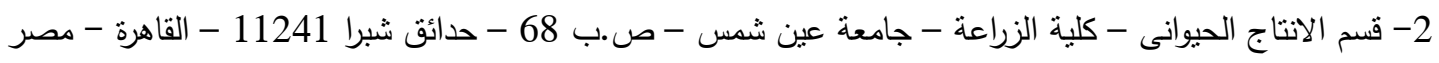 \\ *Corresponding author: Marwamohamedsaleh18@Gmail.com
}

Received 11 June, 2018

Accepted 30 July, 2018

البروتين مقارنة بيقيـة المجموعات التجريبية. تم تقدير

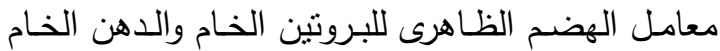

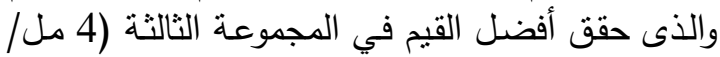

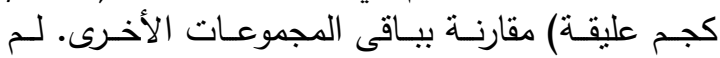

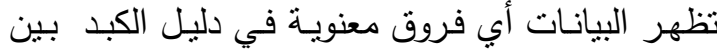

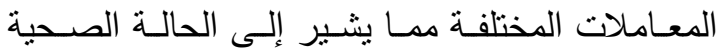

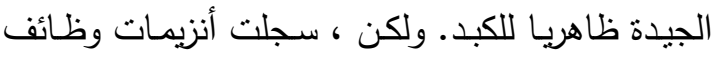

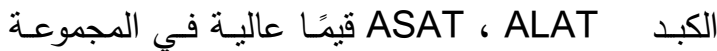

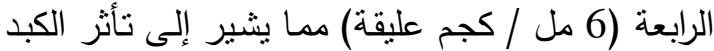

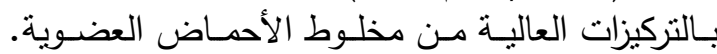

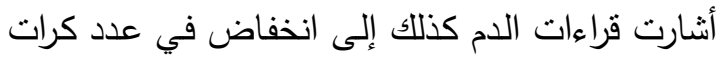

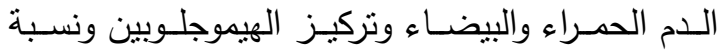

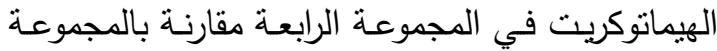

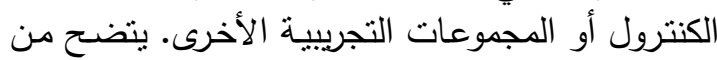

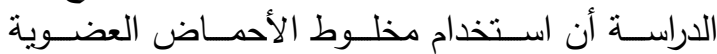

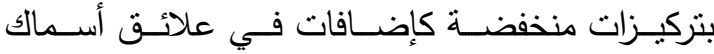

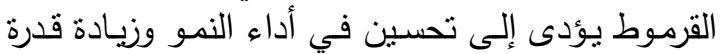
الأسماك على الاستفادة من العليقة وتحسين معاملاء الحسات

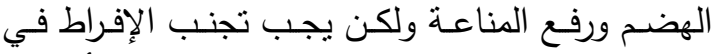
استخدامها بمستويات عالية لهـا قد نسببه من أضرار صحية خاصة في الكبد وصورة الدم.

الكلمات الدالة: أسماك القرامبط، الأحماض العضوية، آداء النمو، معاملات الهضم ، المناعة. 